ROCZNIKI KULTUROZNAWCZE

Tom/Vol. XI, numer/number $3-2020$

DOI: http://dx.doi.org/10.18290/rkult20113-4

PASQUALE BASTA

\title{
FROM DESPAIR TO FAITH: THE STILLING OF THE STORM
}

On 27 March, 2020, Pope Francis raised to the Lord a prayer of supplication in the name of the whole of humanity, seeking an end to the Covid19 pandemic. Still alive in all our memories are the splendid reflections which he offered under a pouring rain which hammered on the cobbles of St Peter's. The Holy Father took his cue from the text of Mark 4:35-41, the famous account of the stilling of the storm. He chose a passage that is certainly difficult and, in many ways, irritating, given that it does not actually correspond to what we are living through in these difficult days. In fact, today, despite the numerous prayers which have been addressed to him from many people and at many different times, God has not yet freed humanity from this scourge; rather, it gets worse by the moment. Just as he still does not save the thousands of Africans, including so many women and children, who are drowning in the Mediterranean Sea each year, probably at the very moment in which they are pleading to him, seeking his help while the water comes up to their throats and they are about to die. Why do these terrible tragedies happen? At the stilling of the storm, the disciples prayed and were saved, but so many people of today have no one who snatches them from danger, despite their long prayers. Thus, the pericope commented on by the Pope could be described with good reason as false or a great deception because it is not in fact true that God intervenes. So many peoples call on him from hospital wards or from their beds at home without receiving answer or help. At this point, along with the atheists of all times and all places, it is legitimate to think that $\mathrm{He}$ simply does not exist. Or else that he has eyes only for his few true disciples. Or even that he lets human history proceed on the path of its tragic dramas without his being interested in the slightest, far

Prof. Pasquale BASTA-Pontifical Urbaniana University, Vatican City; e-mail: donpasquale basta@gmail.com. ORCID: https://orcid.org/0000-0003-3972-5853. 
away as he is in his heaven. In the face of these enormous questions, it is more urgent than ever to reread the passage of the stilling of the storm, seeking to interpret it in depth so as to grasp its fundamental meaning which does not actually consist in the search for a miracle or the wonderful intervention of a God who frees from difficulty those who turn to him.

\section{THE TRIPLE ATTESTATION}

The passage of the stilling of the storm is found in all three Synoptics but with some not insignificant differences on which we must reflect ${ }^{1}$ :

\begin{tabular}{|c|c|c|}
\hline МАтт 8:23-27 & MARK $4: 35-41$ & LUKE 8:22-25 \\
\hline $\begin{array}{l}{ }^{23} \text { When he got into the boat, his } \\
\text { disciples followed him. }\end{array}$ & $\begin{array}{l}35 \text { On that same day, when evening } \\
\text { had come, he said to them: «Let } \\
\text { us cross over to the other side». } \\
{ }^{36} \text { And, leaving the crowd, they took } \\
\text { him with them, just as he was, in } \\
\text { the boat. There were also other } \\
\text { boats with him. }\end{array}$ & $\begin{array}{l}22 \text { One day, it happened that Jesus } \\
\text { got into a boat with his disciples } \\
\text { and said to them: «Let us cross } \\
\text { over to the other side of the lake». } \\
\text { And they took to sea. }\end{array}$ \\
\hline $\begin{array}{l}{ }^{24} \text { And behold, there arose a great } \\
\text { storm on the sea so that the boat } \\
\text { was swamped by the waves; but } \\
\text { he was sleeping. } \\
{ }^{25} \text { Then they went to him and woke } \\
\text { him, saying: "Save us, Lord, we } \\
\text { are perishing!». }\end{array}$ & $\begin{array}{l}{ }^{37} \text { There was a great storm of wind } \\
\text { and the waves spilled into the boat } \\
\text { so that it was now full. } \\
{ }^{38} \text { He was in the stern, on a cushion, } \\
\text { and was sleeping. Then they woke } \\
\text { him and said to him: «Master, do you } \\
\text { not care that we are perishing?». } \\
{ }^{39} \text { He arose, threatened the wind } \\
\text { and said to the sea: «Quiet, be } \\
\text { still!». The wind ceased and there } \\
\text { was a great calm. }\end{array}$ & $\begin{array}{l}{ }^{23} \text { Now, while they sailed, he fell } \\
\text { asleep. A storm of wind battered } \\
\text { down on the lake, they took on } \\
\text { water and were in danger. } \\
{ }^{24} \text { They went to him and woke him, } \\
\text { saying: «Master, master, we are } \\
\text { perishing!». } \\
\text { And when he had woken, he } \\
\text { threatened the wind and the stor- } \\
\text { my sea: they ceased, and there } \\
\text { was a calm. }\end{array}$ \\
\hline
\end{tabular}

\footnotetext{
${ }^{1}$ For the methodology and the synoptic comparison, I must immediately declare myself indebted to my teacher and doctorvater Jean-Noël Aletti. It is to his practical exercises during the seminars of narrative analysis and typology at the Pontifical Biblical Institute that I owe much of my own little competence with regard to the Synoptics. Similarly, for some of the following considerations, I refer to Jean-Noël AletTI, Gesù una vita da raccontare. Il genere letterario dei vangeli di Matteo, Marco e Luca (Roma: San Paolo Edizioni, 2017); as a text of synoptic work, Angelico PopPI, Sinossi e commento esegetico-spirituale dei quattro vangeli (Padova: Edizioni Messagero Padova, 2012), is very useful.
} 


\begin{tabular}{|c|c|c|}
\hline $\begin{array}{l}{ }^{26} \text { And he said to them: «Why are } \\
\text { you afraid, people of little faith?». } \\
\text { Then he rose and threatened the } \\
\text { winds and the sea, and there was } \\
\text { a great calm. }\end{array}$ & $\begin{array}{l}{ }^{40} \text { Then he said to them: «Why are } \\
\text { you afraid? Do you not have faith } \\
\text { yet?». }\end{array}$ & $\begin{array}{l}{ }^{25} \text { Then he said to them: «Where is } \\
\text { your faith?». }\end{array}$ \\
\hline $\begin{array}{l}{ }^{27} \text { Full of wonder, they all said: «Who } \\
\text { on earth is this, that even the } \\
\text { winds and the sea obey him?». }\end{array}$ & $\begin{array}{l}{ }^{41} \text { And they were seized with great } \\
\text { fear and said to one another: } \\
\text { «Who is this, then, that even the } \\
\text { wind and the sea obey him?». }\end{array}$ & $\begin{array}{l}\text { Afraid and awestruck, they said to } \\
\text { one another: «Who is this, then, } \\
\text { who commands even the winds } \\
\text { and the water, and they obey } \\
\text { him?». }\end{array}$ \\
\hline
\end{tabular}

From a rapid comparison of the three passages, there already emerges clearly a mark of difference that is quite curious and enigmatic: Matthew reverses Mark and Luke in an important point. In Matt 8:26b, the injunction addressed to the wind and the sea falls after the question about the nature of the disciples' faith. However, in Mark 4,39b and Luke 8:24b, the opposite happens: Jesus first calms the storm and only then asks the question about their faith. Thus, the text proceeds in a different manner in what is an important point. But other details also receive modifications of significance which demand an in-depth analysis which must be conducted on the basis of an adequate synoptic comparison.

\section{MATTHEW'S VERSION}

The narrative plot of Mt 8:23-27 is rather simple in its linear development:

$\begin{array}{ll}\text { v. } 23 & \text { presentation of the situation } \\ \text { vv. } 24-25 & \text { complication } \\ \text { v. } 26 & \text { transformative action } \\ \text { v. } 27 & \text { question about Jesus }\end{array}$

In v. 26, the situational drama is interrupted with the occurrence of the transformative action which consists in the establishment of a great calm. In this way, the complication is resolved and finishes completely. However, if the situation is completed, the same cannot be said for the revelatory drama which continues for another verse, v. 27, in which is located the classical question of the anagnorisis: "Who is this then?". A little earlier, Jesus in person had posed a dramatic question: "Why are you afraid?". A question to 
which the disciples do not reply, other than by themselves, in their turn, formulating the question as to the identity of the one who has just calmed the winds and the sea. If the texts continues after the end of the situational drama, it is a sign that the nucleus of the account lies not so much in the miracle but rather in the unveiling of the revelatory drama which is wholly focused on the real identity of Jesus. The significance of the passage turns not on calming fears but only on showing that Jesus is God.

Moreover, many details of the pericope already pointed in this direction. At the height of the storm, the disciples turned to Jesus using the words typical of a classic psalmic prayer in which the worshipper finds himself in a desperate situation. The water reaches his throat, and so the psalmist raises a fervent supplication to his God. The disciples do the same at the moment

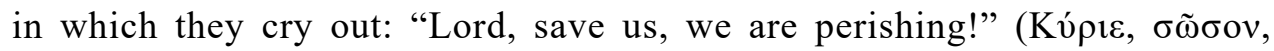
$\dot{\alpha} \pi \mathrm{o} \lambda \lambda \dot{u} \mu \varepsilon \theta \alpha$ [Kýrie, sōson, apollýmetha]). In this plea, we find the whole of the psalter with its structure:
a. Invocation of the Name
b. Request for help
Lord (Adonai)
help me
c. Motivation
for I am dying ( $k i / o t i)$

This is the same structure which we observe, more or less, in the psalms of praise also:
a. Invocation of the Name
Yah
b. Exhortation
Praise (alleluja)
c. Motivation
for his mercy is eternal (ki leolam hasdo).

The verb $\alpha \dot{\alpha} \mathrm{o} \lambda \lambda v ́ \mu \varepsilon \theta \alpha$ [apollýmetha] is in the present indicative so that it could well be translated as "we are dying," an expression which makes clear that the process has already begun but not yet finished. Moreover, we are within a dramatic situation in which death is felt to be near but has not yet happened. The waters have reached the throat, but there is still a chance of survival. In this predicament, the disciples see Jesus as the one who is able to save them by virtue of his ability to intervene in the same ways as those adopted by God in the OT in his dealings with the psalmist who was praying to him. In the moment in which the companions of his voyage address Jesus with the words of the Psalter, they show that they have a certain faith in him. So why then does the Lord call them ó $\lambda$ ıүó $\pi$ $\sigma \tau 0$ [oligópistoi] immediately afterwards? Because clearly behind their prayer there still lurks a great deal of despair and certainly not the faith which Jesus is trying to convey to them.

Among the details of the revelatory drama, we notice that, at the level of the identity markers, the first is the appellation kúpı [kýrie] which, in Matthew, 
renders Adonai and refers already to the risen Lord, living and present within his community. The one who intervenes to help his disciples is certainly the pre-Easter Jesus who historically stilled a storm, but he is still more the risen, post-Easter Lord who frees humanity from the great storm of death which touches us all sooner or later by virtue of the victory which he obtained over our great enemy on the morning of Easter. The climax of the revelatory drama is reached later with the powerful question of v. 27: "Who on earth is this, that even the winds and the sea obey him?"2 In the OT, only God was able to save people from storms or hurricanes. But now the same seems to be being said of Jesus too. So what is the Christology here? High or low? We have to infer it from the whole of the account because the pericope does not provide any explicit or direct Christological declaration. In fact, the passage closes with a question about Jesus' identity, a question which no longer has anything to do with the situation that has just ended but goes well beyond the miracle, reaching the highest notes, though these can be inferred directly from the miracle itself. The same narrative dynamic occurs in many other accounts of miracles where at the end we get a glimpse of a question relating to Jesus' identity. Moreover, many miracles have a clear Christological purpose in the sense that they reveal a fundamental aspect of Jesus' person, human and divine.

Concerning the construction of the characters, Mark's text is simple and clear. Jesus is described as one who is able to rule over the wind and the storm. But only God enjoyed such power in the OT. In the gospels, it is never said directly that Jesus is God, except for John 20 where Thomas exclaims: "My Lord and my God!" However, in many pages, Jesus is already being preached as God, albeit indirectly, as when, for example, he performs the same works as those carried out by God in the OT. What is predicated of the one in the OT is predicated also of the other in the same way in the NT.

In Matt 8:27, the final question is placed in the mouth of the $\alpha v \theta \rho \omega \pi \mathrm{or}$ [ánthrōpoi] and not the $\mu \alpha \theta \eta \tau \alpha i$ [mathètai]. Why this change of characterisation between v. 23 and v. 27? Probably because Matthew is emphasising the man/God relation, showing that he is concerned with men who very gradually are coming to recognise their God. Little by little, and very subtly, therefore, the narrator makes his readers advance in the knowledge they have of Jesus. And, in fact, the disciples are men who, for all their slowness, will

\footnotetext{
${ }^{2}$ Concerning the pragmatic and communicative value of the two questions of Matt 8:26a and $27, b$ cf. Stefano ZENI, "È il Signore che salva. Studio pragmatico di Mt 8,23-27," Studia Patavina 67 (2020), no. 1: 35-47.
} 
enter step by step into the anagnorisis of Jesus. In this connection, we notice also that Jesus is sleeping and then at, a certain point, he wakes up, an action that is fittingly expressed by rection, a sign that, here already, there is some kind of reference to the Risen One, living and operating within his community. The post-Easter One is already at work in the stilling of the storm, a proleptic liberation from an experience of possible death compared with the greater and even more radical emancipation of death obtained definitively by the redemption with which Christ ransomed the entire human race. The men in the boat turn to the pre- and post-Easter Lord, imploring his help. But why call the disciples ò $\lambda$ เó $\pi 1 \sigma \tau o r$ [oligópistoi] if they have prayed in the same way as the psalmists? Perhaps the psalmists were without faith when they were praying? Certainly not ${ }^{3}$, but they had still not heard speak of resurrection except in an occasional and sporadic way. Something which the disciples of Jesus must have been used to hearing about, however, from their post-Easter faith in the resurrection. The little faith for which they were blamed concerns not so much the horizon of an earthly salvation in relation to the water which is reaching their throat but rather their relationship with eternal life.

\section{SYNOPTIC COMPARISON}

\subsection{NarRatival CHARACTERISTICS TyPiCAL OF EACH EVANGELIST}

Synoptic comparison is an operation that is often instructive, especially when it shows how some textual movements differ according to the aspect which each evangelist wishes to underline or emphasise. ${ }^{4}$ In general, Mark

\footnotetext{
${ }^{3}$ For the reading of our passage along the lines of care for the environment, the theology of creation and the current ecological crisis, cf. Nicola Di BIANCO, "La 'tempesta sedata' (Mt 8,23-27): un miracolo ecosoteriologico?" Asprenas 57 (2010), no. 3: 331-344.

${ }^{4}$ On the gospel as a literary genre, cf. Detlev Dormeyer, "Die Kompositionsmetapher 'Evangelium Jesu Christi, des Sohnes Gottes' Mk 1.1 Ihre theologische und literarische Aufgaben in der Jesus-Biographie des Markus," New Testament Studies 33 (1987), no. 3: 452-468; Jean-Noël Aletti, L'arte di raccontare Gesù Cristo. La scrittura narrativa del vangelo di Luca, trans, Lucio Sembrano (Brescia: Queriniana, 1991); Richard A. BuRridge, Che cosa sono i vangeli? (Brescia: Paideia, 2008); Armin D. BAUM, "Biographien im alttestamentlich-rabbinischen Stil. Zur Gattung der neutestamentlichen Evangelien," Biblica 94 (2013), no. 4: 534-564; Graham N. STANTON, Gesù e il «vangelo» (Brescia: Claudiana, 2015); Justin Marc SмITH, Why Bios? On the Relationship between Gospel Genre and Implied Audience (London: T\&T Clark, 2015); Luciano ZAPPELLA, "Euanghelion: il genere letterario dei Vangeli," Bicudi. Bibbia Cultura Didattica, accessed 6
} 
takes more time over the initial description of the situation which precedes each individual account of a cure or miracle ${ }^{5}$ because he likes to emphasise the difficulties which have to be confronted to believe in Jesus' power. One thinks, for example, of the crowd who, in so many Marcan episodes, are a material obstacle to the arrival of the sick person before the Lord (Mark $2: 4)$ or the people who stop him while he is trying to reach the house of the patient (Mark 5:22-43). In our episode, the accumulation of the difficulties which precede the miracle is observed in the attention to the details relating

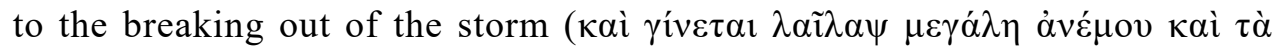

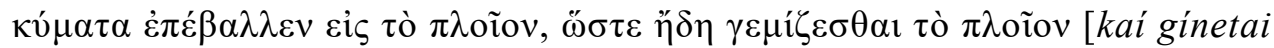
laílaps megále anémou kai tá kýmata epéballen eis tó ploíon, hóste ēdē gemizesthai tó ploíon]) or to the details about the stern and the cushion ( $\dot{\varepsilon} v$

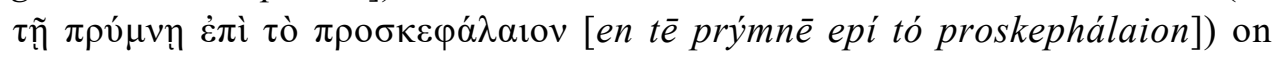
which Jesus is sleeping very deeply. In emphasising the enormity of the storm which the Lord has to face, Mark manages to underline the extraordinary power of Jesus still better.

In a diametrically opposite way, Matthew prefers instead to reduce the narrative skeleton to the essential, without meandering into details he considers secondary. In this way, his account is constantly avoiding any element which could divert the attention from what he considers really primary, that is to say, the relationship between Jesus and the people or situations with which he has to deal. If Mark's narrative eye is focused on many tiny details ${ }^{6}$, Matthew uses the wide-angled lens to capture only Jesus and his interlocutors, relegating everything else to the background. ${ }^{7}$ This Matthean peculiarity is visible in our episode, given that the recounting of peripheral aspects is extremely scanty.

Finally, Luke's typical characteristic consists in always limiting the initial situation and the preliminary notes of each pericope, accounts of miracles included, because his attention is concentrated rather on the final reaction of the people to the wonder and possibly on a word of the Lord which seals up the whole episode. ${ }^{8}$ The same features can be observed in our

February, 2017, http://www.bicudi. net/node/45; Pasquale BASTA, "Il Vangelo come genere letterario e forma di linguaggio," Italia Francescana 43 (2019), no. 1: 47-65.

${ }^{5}$ Rightly, Eve-Marie BeCKer, Das Markus Evangelium im Rahmen antiker Historiographie (Tübingen: Mohr Siebeck, 2006), 65, describes Mark as «ein Werk sui generis».

${ }^{6}$ On the Markan narrative cf. David RHOADS, Joanna Dewey, and Donald MichIE, Mark as Story: An Introduction to the Narrative of a Gospel, $3^{\text {rd }}$ ed. (Minneapolis: Fortress Press, 2012).

${ }^{7}$ On the Matthean narrative cf. Dorothy Jean WeAver, The irony of power: the politics of God within Matthew's narrative (Eugene: Pickwick Publications, 2017).

${ }^{8}$ On the Lukan narrative cf. Jean-Noël ALETTI, L'art de raconter Jésus Christ. L'écriture 
account where the evangelist limits himself initially to saying that the

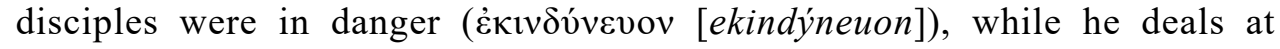
greater length with the reaction which follows the miracle.

\subsection{The Structure of THE Miracle in MARK AND LUKE}

Equipped with these preliminaries, it is now possible to go into the synoptic comparison more deeply, pointing out, as we go, the similarities and differences, aware that the textual phenomena are not only to be observed but still more to be interpreted ${ }^{9}$.

The literary context of the stilling of the storm in Mark 4:35-41 is a journey across pagan territory. ${ }^{10}$ We have already noticed how, in an interesting way, in Mark and Luke, the narrative gets down to the criticism of the o $\lambda$ iro-

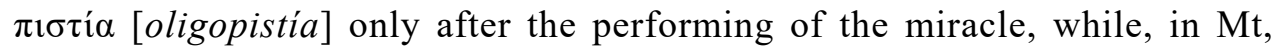
the exact opposite takes place: after the observation about the disciples'

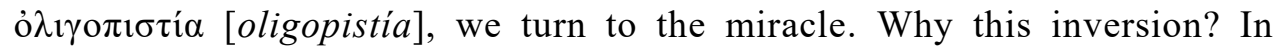
Matt, Jesus' rebuke occurs earlier than in Mark and Luke where it follows and does not precede the instruction to the wind and sea. Why does Matt place Jesus' rebuke of the disciples before the miracle whereas, in Mark and Luke, Jesus first calms the winds and the sea and only afterwards allows himself to censure his travelling companions? How do we interpret this inversion? There are many possible explanations. Perhaps Mark and Luke wish to underline that Jesus responds immediately to the cry for help while only, at a later stage, when things settle down, does he start to criticise his disciples. If so, the sense of the inversion would lie in the fact that salvation always precedes any rebuke: first Jesus saves, then he admonishes. From a different perspective, on the other hand, Mt creates a different order because he is perhaps emphasising the opposite aspect: it is necessary to have faith to obtain a miracle. In this case, there would be greater emphasis on the inability of the disciples to believe seeing that, in the broader context, they had already been witnesses of so many other wonders. A lack of faith to which Jesus reacts by granting a miracle even greater than the previous ones, a further

narrative de l'évangile de Luc (Paris: Éditions du Seuil, 1989); IDEM, Il Gesù di Luca (Bologna: EDB, 2012).

${ }^{9}$ There is a careful synoptic comparison of the three pericopes which is constructed not on the basis of the Two Source theory but on that of the three stages of composition (Mark, DeutMark, Matt/Luke) in Albert Fuchs, "Die 'Seesturmperikope' Mk 4:35-41 parr im Wandel der urkirchlichen Verkündigung," Studien zum Neuen Testament und seiner Umwelt 15 (1990): 101-133.

${ }^{10}$ Cf. Jean-François Desclaux, "L'esperance dans les chapitres 4 et 5 de l'évangile de St Marc," Theologia Catholica 53 (2008), no. 4: 21-26. 


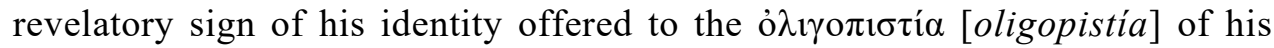
companions.

However, the differences do not end here given that the disciples' cry to Jesus in Mark 4:38 is different ("Master, do you not care [ởv $\mu \varepsilon \dot{\lambda} \varepsilon \varepsilon$ бol, oun mélei soi] that we are perishing?") from the more solemn Matthean plea of $8: 25 \mathrm{~b}$ ("Save us, Lord, we are perishing!"). This question addressed by the disciples to the sleeping Jesus is a uniquely Markan element and has all the features of a really strong memory of the Lord ${ }^{11}$. The background of the Markan sentence is no different from Matthew's because both cases depend on the Psalms. The disciples of Mark 4:38 are much more offensive compared with what they say in Matt 8:25b. However, their audacity is not an absolute novelty because the question they direct at Jesus echoes the same insolence with which many of the psalmists address God when they use irreverent and brazen expressions. In Mark 4:37, the danger of death is perceived as imminent given that the boat is now on the point of sinking since it is already almost completely full of water. Jesus is sleeping, and his disciples cry to him, saying that they are going to die. They turn to Jesus and not to God, but they use words which are very like those in the psalms of supplication where God is asked "Why are you sleeping, Lord?" (Ps 43:24). What is interesting, we repeat it again, is the fact that the disciples address Jesus in the same way in which the worshipper of the Psalms addresses God in the OT. Moreover, the dramatic situation which they experience is perfectly identical to that of the ancient psalmists: in both cases, the end is near. At this point, nothing remains but to wake him, badger him and press him to act with whatever means. That means that the disciples have faith in Jesus; they know who he is ${ }^{12}$. If they ask him such an insolent question, it is only because they are convinced that their master can intervene on their behalf right in the middle of the storm. Yet, although they implore him with psalmic expressions, he rebukes his companions, a sign that the Lord is seeking a different attitude. But what? Or else are we even forced to think that Jesus is making himself the subject of bizarre behaviour when he rebukes his followers on account of their lack of faith, given that they have called on him in their danger and certainly not on God. We must go deeper

\footnotetext{
${ }^{11}$ On the strength of rebuke or prayer contained in the expressions which the disciples address to Jesus, cf. Aldo MARTin, "Il senso della fede e le ambivalenze necessarie in Mc 4,35-41," Studia Patavina 54 (2007), no. 3: 513-536.

${ }^{12}$ On the kerygmatic significance of the text, cf. Albert Fuchs, "La perícopa de la "tempestad calmada' (Mc 4,35-41 par) en el kerigma de la Iglesia primitiva," Estudios Bíblicos 48 (1990): 433460 .
} 


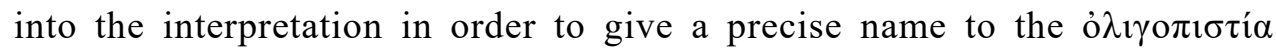
[oligopistia] for which the Lord rebukes his disciples.

The text of Luke 8:23-25 has more neutral shades but is also clearer: Jesus does not rebuke his companions because of their lack of faith but limits himself to asking simply: "Where is your faith?". Here, it appears clear that Jesus does not regard the heartfelt supplication addressed to him a little earlier as a sign of faith, but rather of the opposite. Consequently, the question addressed to the disciples would be the equivalent of an invitation for them to recover their faith, seeing that Jesus makes the effort to find it.

A final question concerns a detail which could raise difficulties: if they are with Jesus, why on earth does the storm affect them. Many times, the Psalter recites that one who trusts in God will never be harmed by anything. Yet, in the Synoptic pericope, the storm upsets the disciples precisely while they are with their Lord and Master. A sign that his presence does not provide protection against the dangers of history. Why? Where is the account taking us?

\subsection{The FINAL QUESTION}

It remains to examine the final verse of each version. All three Synoptics open with a reference to the disciples' state of mind. However, this is presented by each of them in a quite different way: Mark 4:41 emphasises

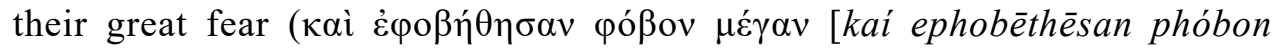
mégan]); Matt 8:27 emphasises their wonder ( $\dot{\varepsilon} \theta \alpha v \mu \alpha \sigma \alpha v$ [ethaúmasan]); while Luke 8:25b prefers to combine the two elements of fear and wonder ( is a matter of grasping what point it is which the evangelist wishes to stress. This is not easy given that the narrative stages of the triple Synoptic account are very similar. Moreover, the three different accounts all conclude with the final reaction of the disciples who pose a question about the identity of Jesus. What is the emphasis of each version? Does the emphasis in MattMark-Luke fall on the final question or do we have to think of another stage of the narrative? In general, in the gospel accounts, the most important moment is to be found in the words of Jesus. In the stilling of the storm, however, the Lord's only intervention in oratio recta, attested by all three Synoptics, concerns only the question relating to the disciples' lack of faith (Matt 8:26a; Mark 4:40; Luke 8:25a). A question which gives rise to a fur- 
ther one, this time in the mouth of the disciples (in Mark and Luke but not in Matt 8:27a who opts for the more generic and enigmatic ö $v \theta \rho \omega \pi$ or [ánthrōpoi]) which allows for the appearance of a kind of final recognition of the lordship of Christ by all who were present at the extraordinary wonder of the stilling of the storm. In a different way, the order to the sea and the wind is recorded in direct speech only by Mark whereas Matt and Luke make use of a simple narrative statement. In the same way, Jesus' initial invitation for them to cross over to the other side of the lake occurs in oratio recta only in Mark and Luke but not in Matt. And usually such a request does not constitute the central element of the account but only its starting point. Consequently, could these three interventions of Jesus be the fulcrum of the narrative, at least in Mark, the evangelist who certainly emphasises the Lord's words more than the other two Synoptics? But if so, we would have to think of a different nucleus for Matt and Luke since they both tone down Jesus' direct interventions considerably while Matt even reduces them to only one. It would be different if we decided to give priority to the subsequent question of the disciples, attested this time in oratio recta by all three Synoptic versions. In fact, on the basis of this last hypothesis, the centre of gravity on which the entire narrative arch leans and towards which it tends would be constituted by the anagnorisis which is hidden behind the final question, a recognition that seals the account on a questioning note, undulating between fear, distress and great wonder.

That the recognition of the protagonist of the stilling of the storm is the principal object of the account emerges from other details. Thus, in the previous episodes of Mark, for example, we are certainly in the presence of a heightened rhetoric relating to Jesus' identity in which, a little at a time, the various episodes are gradually being clarified. He is being revealed in his deepest identity. He is not just a sublime teacher of doctrine or a supreme exorcist, a new prophet or a phenomenal healer, but someone greater about whom the people and the disciples ask increasingly coherent questions day after day. Moreover, in the Markan redaction of the stilling of the storm, the brazen rebuke which the disciples address to Jesus is a striking indication of how they now expect the greatest of thigs from him, a sign that they are already aware of the fact that their master can perform extraordinary miracles. Right from the beginning, therefore, the emphasis turns on the identity of Jesus, given that the disciples already expect much from him but still do not understand in depth with whom they are dealing. For this reason, at the end of the account, there is a question of capital importance to which there is no re- 
ply. In this way, the evangelist has managed to guarantee emphasis and narrative tension of a high dramatic level. However, only at the end of the pericope are we able to grasp how, from the initial reproof addressed to Jesus until the concluding question of the disciples, every detail of the account from the beginning was at the service of the unveiling of Christ's identity.

If one broadens the exegetical attention to the previous context, it becomes clear that, in the course of the drama in all three Synoptics, the question with which the episode of the stilling of the storm concludes is one of the first really serious and important questions about Jesus' identity, a sign that the problem had begun to become increasingly pressing after a beginning of public ministry which was absolutely innovative and impressive in many of its features. Beyond the differences of detail which emerge from the reading in parallel, the three Synoptics agree in conferring the same narrative emphasis on the disciples' final question, one of the first questions which begins to hide a clear Christological declaration even if one that is in the form of a question and not an explicit and direct acknowledgement.

Before concluding the Synoptic comparison, a final consideration emerges. Generally speaking, the gospel pericopes close with the description of the final situation which has been created through Jesus' intervention. After the initial situation has been complicated, the tension has mounted gradually until it is definitively resolved thanks to the transformative action which produces a new state which coincides with the final situation. In the miracle accounts, the beginning sees the introduction of the characters who will act in the pericope, among which appear, alongside the protagonist, Jesus, sick people or the possessed or difficult situations on which the Lord places his transformative action which consists in a miracle or healing. At this point, the narrator often goes on to describe the final situation inaugurated by the intervention which resolved the narrative knots. And on these notes, which often reprise elements of the initial situation but now modified radically by the development of the story, the pericope closes in a full and extensive way. In the stilling of the storm, however, once the supernatural phenomenon has been completed, the account does not finish by describing the final situation of the

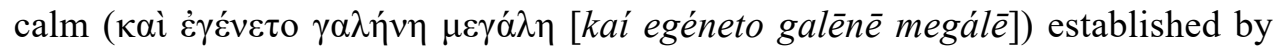
the Lord after he has ordered the winds and the sea to be still. On the contrary, the passage knows a further, and in many ways unexpected development marked by Jesus' statement about the lack of faith of his companions and on the subsequent reaction of the disciples, fearful and in wonder to the point of posing

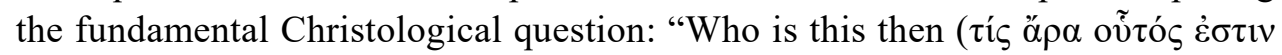
[tís ára hoútós estin]), that even the wind and the sea obey him?" The question 


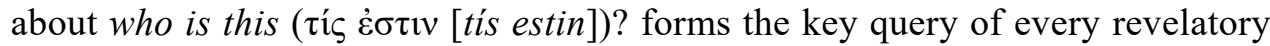
drama at the moment in which the account aims to unveil the identity of the protagonist. In the pericope of the stilling of the storm, after the weather has returned to normal, the text could finish there and then but yet it proceeds a little bit further until it closes with the question about the person of Jesus. But if the Christological question continues after the description of the final solution, that means that, for the evangelist, the most important aspect is represented not by the miracle of the stilling of the storm but what that reveals about the identity of the protagonist of the story. The situational drama finishes with the reference to the great calm but the revelatory drama continues for a further verse, this time focused on the true objective of the narrative as a whole.

\section{THE PSALMIC BACKGROUND}

From an intertextual perspective ${ }^{13}$, many details in the account of the stilling of the storm refer to various pages of the OT in which Yhwh is shown as dominating over the powers of the atmosphere. In general, commentators underline the connection with Ps 106 (107):23-3014:

\footnotetext{
${ }^{13}$ Lucia RoDLER, I termini fondamentali della critica letteraria (Milano: B. Mondadori, 2004), 93-94, recalls that the term "intertextuality" was used for the first time by Julia Kristeva in the course of a conference on the languages of criticism held in Baltimore in 1966. Even if intertextual interpretation was already found in the theories of Ferdinand de Saussure on the dissemination of the verbal theme generating a text; of Jurij $\mathrm{N}$. Tynjanov on the evolution of the literary system through series of correlated works; of Michail Bachtin on interdiscursive plurivocity; of Erich Auerbach on the relationship of figurality between the Old and New Testaments. However, none of these authors defines the phenomenon of intertextuality better than Kristeva, when, in her essay of 1967, La parola, il dialogo e il romanzo, she reiterated on several occasions «each text is constructed as a mosaic of quotations». In a concise way, RODLER, I termini, 94, summarises Kristeva's proposal in these terms: «a dialogue between the languages of the writer, the recipient and the cultural context, with the word which is acting in a horizontal sense, when it involves emitter and receiver, and in a vertical sense, when regarded from the part of previous or different writers. This unlimited, heterogeneous and dynamic series of codices overturns the myth of the originality of the author, on the one hand, while, on the other hand, it puts into question the formalist and structuralist idea of the focused and coherent text [...] Moreover, by describing the social nature of literary writing, through Roland Barthes intertextuality made obsolete the binary system of sources which had dominated French comparativistics». From that moment, Kristeva's creature, intertextuality, continues to live in name even if it assumes new definitions from time to time. For a systematisation, which still acts as a base model today, cf. the five famous distinctions into intertext, hypertext, metatext, paratext and architext, as formulated by Gérard GENETTE, Palinsesti (Torino: Einaudi, 1997).

${ }^{14}$ The intertextual process is well indicated by Timothy J. STONE, "Following the Church Fathers: An Intertextual Path from Psalm 107 to Isaiah, Jonah, and Matthew 8:23-27," Journal of
} 
${ }^{23}$ Others, who went down into the sea in ships and traded on the great waters,

24 saw the works of the Lord and his wonders in the deep.

${ }^{25}$ He spoke and raised a stormy wind, which lifted the waves:

${ }^{26}$ they mounted up to heaven, they descended into the depths; their courage failed in their danger.

27 They reeled and staggered like drunken men: they lost all their ability.

${ }^{28}$ In their trouble they cried to the Lord, and he delivered them from their distress.

29 The storm was reduced to silence, hushed the waves of the sea.

${ }^{30}$ They rejoiced to see the calm, and he led them to the port they desired.

In effect, the situations in which the psalmists and the disciples find themselves is objectively the same: both are in danger of death, they cry to the Lord and he comes to their aid by causing a great calm. However, the coincidence is only semantic and not linguistic since the words used in the two passages are not actually identical. This means that the Synoptic text is only adopting well-known themes but not that the psalm is inspiring the narrative movement of the New Testament passage. Starting from Ps 106(107), one can only say that there is an attitude common to the two texts: the disciples find themselves in the same situation that happened centuries previously to so many people in the OT who called for the divine intervention at a time when they were threatened by the peril of death. In the same way, the comparison between God and Jesus is developed on the basis of a complete parallel: the situation in which Jesus finds himself in relation to his disciples is the same as that of Yhwh as protagonist before the worshippers of the psalm of supplication. However, if the situation of Ps 106(107) can be compared with the stilling of the storm in its broad features, the same is not the case for the rebuke Jesus addresses to his companions. In fact, the people spoken of in the psalm were never accused of lack of faith by contrast with what Christ says to his disciples when he accuses them of o $\lambda \iota \gamma o \pi \imath \sigma \tau i \alpha$ [oligopistía]. Jesus' response to their requests for help, in some ways obscure and incomprehensible, is at this point still more difficult to interpret because it is not matched in any other text of the OT. Yhwh never brands worshippers with little or no faith. So why then does Jesus do so?

Another passage of definite interest because of its important contacts with the account of the stilling of the storm is Ps 43(44),24-27:

Theological Interpretation 7 (2013), no. 1: 37-55, an article which one must criticise for the fact that it attributes excessive importance to Jonah as background to our pericope while, in reality, the points of contact between the two passages are very tenuous and absolutely unable to be typologised because of the numerous differences between Jonah and Jesus. 
${ }^{24}$ Rouse yourself! Why are you sleeping, Lord? Awake, do not reject us for ever!

${ }^{25}$ Why do you hide your face, forget our misery and oppression?

${ }^{26}$ Our throat is immersed in the dust, our belly is glued to the soil.

${ }^{27}$ Arise, come to help us! Save us for your mercy!

In this second case too, there are clear parallels between Yhwh and Jesus. First of all, in the face of human anguish, it seems that both are sleeping, but then, at a certain point, they wake up and act. In particular, after God has performed his wonders, the worshippers immediately recognise him as Lord of the creation. But the same thing happens with Jesus given that, after the miracle, his disciples pose a question behind which the anagnorisis is hidden. To put the two passages in parallel, therefore, is a valid procedure because, in both texts, there is an emphasis not only on the sleeping but also on the fact that the witnesses find themselves in the presence of the Lord of the creation. But who creates the parallelism? Certainly, in the moment when, first, with their plea for help of a psalmic nature and, then, with their question, loaded with fear and wonder, concerning the real identity of their master, the disciples create a comparison of an Old Testament type in which Jesus is compared with God. For the disciples, there exists a very close correlation between their master and Lord and the Yhwh of the Psalms. The consequences are huge. With what kind of Christology are we dealing here ${ }^{15}$ ? Very high, certainly, seeing that Jesus is being depicted and characterised with the same features as Yhwh. Conversely, what model of discipleship do the Synoptics intend to offer to their readers? In this connection, the answer is more difficult because if, on the one hand, Jesus' companions are described as worshippers on the psalmic model, the same cannot be said about the emphasis on their lack of faith, an aspect completely absent in the key Old Testament texts. If, before the storm, they had already been present at some miracles, why do they still continue to have fear? And why despite their

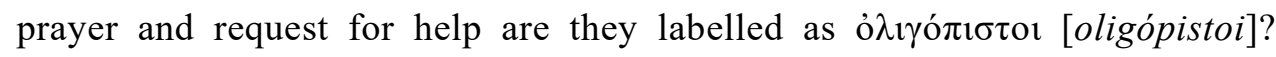
Does the central question of the text concern Jesus or his disciples?

\footnotetext{
${ }^{15}$ For a narratological analysis of Mark's Christology, cf. the excellent Marco VIRONDA, Gesù nel vangelo di Marco. Narratologia e cristologia (Bologna: EDB, 2003).
} 


\section{CONCLUSIONS: FROM DESPAIR TO FAITH}

At the end of our journey, we are finally able to give a better answer to our initial questions and the overall interpretation of the text, especially with regard to the points that are most debated. The ultimate aim of the text concerns the identity of Jesus as God, and he is certainly not at the service of calming human fears. A noble task, but not one which constitutes the special characteristic of the stilling of the storm. From the anagnorisis of his divine identity, then, there originates the response to the theme of the o $\lambda \iota \gamma o \pi \imath \sigma \tau i \alpha$ [oligopistia] which the Lord observed in his disciples. During the storm, they appear not as believers but as people who are desperate, who have totally lost control and clarity of thought. By contrast, the faith to which Jesus recalls them consists in the strong and clear vision of a precise goal. What, ultimately, qualifies faith is its relationship with eternal life and not with however many measures of water are coming up to the throat. The great fear of the disciples resides entirely in the verb $\dot{\alpha} \pi \mathrm{o} \lambda \lambda \hat{u} \mu \varepsilon \theta \alpha$ [apollýmetha], which I, personally, would translate with "we are dying". Here is where the true problem lies. They believe that they are on the point of dying, of perishing. And yet, no! Eternal life exists so that there is no point in having fear of dying because after that will come lasting and imperishable salvation. The disciples

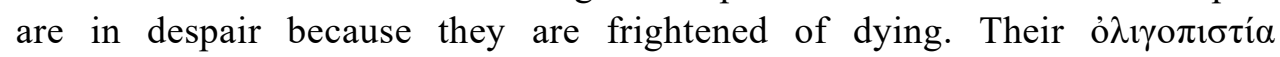
[oligopistia] consists in their not yet having framed the totality of their existence within the perspective of eternal life. Faith puts the fear of death to flight because it opens up to a much broader context which has to do with eternal life and not just the brief lapse of time in which we are pilgrims and strangers in this world. The one who speaks in the stilling of the storm is, yes, the Nazarene of history but still more the Risen One whom the great storm of death will have to obey in sorrow, on a far-off day, the morning of Easter.

\section{BIBLIOGRAPHY}

Aletti, Jean-Noël. L'art de raconter Jésus Christ. L'écriture narrative de l'évangile de Luc. Paris: Éditions du Seuil, 1989 [Italian translation: L'arte di raccontare Gesù Cristo. La scrittura narrativa del vangelo di Luca. Translated by Lucio Sembrano. Brescia: Queriniana, 1991].

Aletti, Jean-Noël. Il Gesù di Luca. Bologna: EDB, 2012.

Aletti, Jean-Noël. Gesù una vita da raccontare. Il genere letterario dei vangeli di Matteo, Marco e Luca. Roma: San Paolo Edizioni, 2017. 
Basta, Pasquale. "Il Vangelo come genere letterario e forma di linguaggio." Italia Francescana 43 (2019), no. 1: 47-65.

BAuM, Armin D., "Biographien im alttestamentlich-rabbinischen Stil. Zur Gattung der neutestamentlichen Evangelien." Biblica 94 (2013), no. 4: 534-564.

Becker, Eve-Marie. Das Markus Evangelium im Rahmen antiker Historiographie. Tübingen: Mohr Siebeck, 2006.

Burridge, Richard A. Che cosa sono i vangeli?. Brescia: Paideia, 2008.

Desclaux, Jean-François. "L'esperance dans les chapitres 4 et 5 de l'évangile de St Marc." Theologia Catholica 53 (2008), no. 4: 21-26.

Di BiAnCo, Nicola. “La 'tempesta sedata' (Mt 8,23-27): un miracolo ecosoteriologico?” Asprenas 57 (2010), no. 3: 331-344.

Dormeyer, Detlev. "Die Kompositionsmetapher 'Evangelium Jesu Christi, des Sohnes Gottes' Mk 1.1 Ihre theologische und literarische Aufgaben in der Jesus-Biographie des Markus." New Testament Studies 33 (1987), no. 3: 452-468.

Fuchs, Albert. "Die 'Seesturmperikope' Mk 4:35-41 parr im Wandel der urkirchlichen Verkündigung." Studien zum Neuen Testament und seiner Umwelt 15 (1990): 101-133 [Spanish translation: "La perícopa de la 'tempestad calmada' (Mc 4,35-41 par) en el kerigma de la Iglesia primitiva." Estudios Bíblicos 48 (1990): 433-460].

Genette, Gérard. Palinsesti. Torino: Einaudi, 1997.

Martin, Aldo. "Il senso della fede e le ambivalenze necessarie in Mc 4,35-41." Studia Patavina 54 (2007), no. 3: 513-536.

PopPI, Angelico. Sinossi e commento esegetico-spirituale dei quattro vangeli. Padova: Edizioni Messagero Padova, 2012.

RhoAds, David, Joanna Dewey, and Donald Michie. Mark as Story: An Introduction to the Narrative of a Gospel. $3^{\text {rd }}$ edition. Minneapolis: Fortress Press, 2012.

RODLER, Lucia. I termini fondamentali della critica letteraria, Milano: B. Mondadori, 2004.

SMith, Justin Marc. Why Bios? On the Relationship between Gospel Genre and Implied Audience. London: T\&T Clark, 2015.

StAnton, Graham N. Gesù e il «vangelo». Brescia: Claudiana, 2015.

Stone, Timothy J. "Following the Church Fathers: An Intertextual Path from Psalm 107 to Isaiah, Jonah, and Matthew 8:23-27." Journal of Theological Interpretation 7 (2013), no. 1: $37-55$.

VIRONDA, Marco. Gesù nel vangelo di Marco. Narratologia e cristologia. Bologna: EDB, 2003.

WEAVER, Dorothy Jean. The irony of power: the politics of God within Matthew's narrative. Eugene: Pickwick Publications, 2017.

ZAPPELlA, Luciano. "Euanghelion: il genere letterario dei Vangeli." Bicudi. Bibbia Cultura Didattica. Accessed 6 February, 2017. http://www.bicudi. net/node/45.

ZENI, Stefano. "È il Signore che salva. Studio pragmatico di Mt 8,23-27." Studia Patavina 67 (2020), no. 1: 35-47. 


\section{FROM DESPAIR TO FAITH: THE STILLING OF THE STORM}

\section{Su m m a ry}

On 27 March, 2020, Pope Francis raised to the Lord a prayer of supplication in the name of the whole of humanity, seeking an end to the Covid-19 pandemic. In that occasion he gave an impressive homily based on the text of Mark 4,35-41, the famous account of the stilling of the storm. The present paper studies the triple attestation in the Synoptics (Matt 8,23-27; Mark 4,3541; Luke 8,22-25), by considering the main difference on which it's necessary to reflect with attention: Matthew reverses Mark and Luke in an important point. In fact, in Matt 8,26b, the injunction addressed to the wind and the sea falls after the question about the nature of the disciples' faith, but in Mark 4,39b and Luke 8,24b the opposite happens: Jesus first calms the storm and only then asks the question about their faith. Why? With different strategies, all three Synoptics show that the disciples are men who, for all their slowness, will enter step by step into the anagnorisis of Jesus. In the course of the drama, the question with which the episode of the stilling of the storm concludes is really serious about Jesus' identity. Beyond the differences of detail which emerge from the reading in parallel, the three Synoptics agree in conferring the same narrative emphasis on the disciples' final question: "Who is this then, that even the wind and the

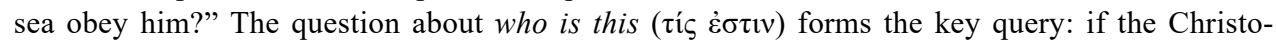
logical question continues after the description of the final solution, that means that, for the evangelists, the most important aspect is represented not by the miracle of the stilling of the storm but what that reveals about the identity of the protagonist of the story. The ultimate aim of the text

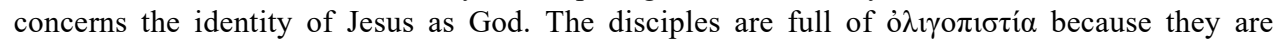
frightened of dying, not yet having learnt the perspective of eternal life: the one who speaks in the stilling of the storm is, yes, the Nazarene of history but still more the Risen One whom the great storm of death will have to obey in the morning of Easter.

Key words: fear; death; faith; anagnorisis; eternal life.

\section{OD ROZPACZY DO WIARY: UCISZENIE BURZY}

\section{Streszczenie}

27 marca 2020 r. papież Franciszek wzniósł do Pana modlitwę błagalną w imieniu całej ludzkości, prosząc o zakończenie pandemii Covid-19. Z tej okazji wygłosił impresywną homilię, opartą na perykopie z Ewangelii według św. Marka 4,35-41, słynnej relacji o uciszeniu burzy. W niniejszym artykule przeanalizowano potrójne świadectwo synoptyków o tym fakcie (Mt 8,2327; Mk 4,35-41; Łk 8,22-25), biorąc pod uwagę główną różnicę, nad którą należy się uważnie zastanowić: Mateusz przestawia w ważnym punkcie kolejność wydarzeń podawanych w relacji Marka i Łukasza. W rzeczywistości w Mt 8,26b nakaz skierowany do wiatru i morza pojawia się po pytaniu o naturę wiary uczniów, a w Mk 4,39b i Łk 8,24b dzieje się odwrotnie: Jezus najpierw uspokaja burzę i dopiero wtedy zadaje pytanie o wiarę uczniów. Dlaczego? Wszyscy trzej synoptycy, stosując różne strategie, pokazują, że uczniowie są ludźmi, którzy, mimo całej swojej opieszałości w myśleniu, wejdą krok za krokiem w anagnorisis Jezusa. W trakcie dramatu pytanie, którym kończy się epizod uciszenia burzy, jest naprawdę ważne, jeśli chodzi o tożsamość Jezusa. Pomijając różnice w szczegółach, które wyłaniają się z równoległego czytania tekstów ewangelicznych, trzej synoptycy kładą w swojej narracji zgodnie ten sam nacisk na ostatnie pytanie uczniów: „Kimże On jest, że nawet wichry i jezioro są Mu posłuszne?”. Pytanie „kim On jest ( $\tau$ í $\dot{\varepsilon} \sigma \tau \imath)$ ?" jest kluczowe: jeśli kwestia chrystologiczna toczy się dalej po opisie ostatecznego roz- 
wiązania, oznacza to, że dla ewangelistów najważniejszy aspekt nie jest reprezentowany przez cud uciszenia burzy, ale przez to, co ujawnia tożsamość bohatera opowieści. Ostateczny cel tekstu dotyczy tożsamości Jezusa jako Boga. Uczniowie są pełni ỏ $\imath$ ıл śmierci, nie znając jeszcze perspektywy życia wiecznego: ten, który przemawia podczas uciszania burzy, jest Nazarejczykiem historii, ale jeszcze bardziej Zmartwychwstałym, któremu wielka burza śmierci będzie musiała być posłuszna w poranek Wielkanocy.

Słowa kluczowe: strach; śmierć; wiara; anagnorisis; życie wieczne. 